Noni Zaharia is with the Department of Sport Management, Florida State University, Tallahassee, Florida. Anastasios Kaburakis is with the John Cook School of Business, Saint Louis University, Saint Louis, Missouri. David Pierce is with the School of Physical Education and Tourism Management, Indiana University-Purdue University Indianapolis, Indianapolis, IN. Address author correspondence to Noni Zaharia at nzaharia@fsu.edu.

Zaharia, Kaburakis, and Pierce

Sport Management Programs in Business Schools

http://dx.doi.org/10.1123/SMEJ.2015-0007

\title{
U.S. Sport Management Programs in Business Schools: Trends and Key Issues
}

\author{
Noni Zaharia \\ Florida State University \\ Anastasios Kaburakis \\ Saint Louis University \\ David Pierce \\ Indiana University-Purdue University Indianapolis
}

\begin{abstract}
The growth of sport management programs housed in (or with formal curriculum-based ties to) a school of business indicates more academic institutions are reconsidering sport management as a business-oriented field. Thus, research is necessary regarding benchmarking information on the state of these academic programs. The purpose of this study is to explore trends on administration, housing, accreditation, faculty performance indicators and research requirements, as well as salaries for faculty and alumni of such programs. Data were submitted by 74 department chairs and program directors employed in U.S. business schools featuring sport management programs. Results indicate that the majority of sport business programs are part of an interdisciplinary department; COSMA accreditation is largely viewed as redundant; and, depending on business schools' accreditation, variability exists concerning faculty performance measures and research impact, as well as faculty and alumni salaries. These findings suggest considerable progress of sport management programs within business schools.
\end{abstract}

Keywords: business schools, higher education administration, business accreditation, faculty measures, research impact, salaries

The numbers of students and degrees earned in United States' business schools surpassed all other academic fields since the 1970s (National Center for Education Statistics, 2013; Walsh, Weber, \& Margolis, 2003), as more individuals are becoming entrepreneurially motivated and seek to develop business savvy (Noorda, 2011). Recessionary times, decreases in enrollment of traditional academic programs (de Onzoño \& Carmona, 2007; George, Valacich, \& Valor, 2005), and broader financial and environmental factors led to business school administrators "looking for the next best thing" to boost enrollments (Noorda, 2011; Tullis \& Camey, 2007). Online and hybrid programs, as well as new and specialized curricula, have been strategies of choice for business schools (Arbaugh et al., 2009). One of the most rapidly growing subdisciplines within business school curricula is "sport(s) business," or "sport management" (Li et al., 2013; Schwarz, 2010). This growth is tied to the growth in the size of the sport industry, which is estimated to be $\$ 485$ billion in 2015 and one of the top 10 industries in the U.S. (Plunkett, 2014). Consequently, many academic institutions have reassessed the focus of their sport management programs and the suitable academic unit in which to house these programs (Li et al., 2013).

There has been considerable dialogue over the past decades regarding which academic unit offers the best fit for sport management programs (Chalip, 2006; Danylchuk \& Boucher, 2003; Jones, Brooks, \& Mak, 2008; Mahony, 2008). In the early 1980s, there were approximately 20 sport management programs in the U.S. (Parkhouse, 1996). The field has seen rapid expansion since that time, growing from 100 programs in 1990 (Kjeldsen, 1990), 
200 in 2000 (Parkhouse \& Pitts, 2001), and over 300 in 2010 (Mathner \& Martin, 2012). To date, 469 institutions house some level of sport management program in the U.S. ("Degrees in Sports," n.d.). Most sport management programs evolved from physical education programs (Boucher, 1998). In the 1990s, the great majority of sport management programs in the U.S. were housed in departments of physical education (Alsop \& Fuller, 2001; Fielding, Pitts, \& Miller, 1991; Sawyer, 1993). By 2010, Schools of Health, Physical Education, \& Recreation (HPER) were still the most popular placement for undergraduate sport management programs with 35\%, but Schools of Business had grown to $25 \%$ of programs (Eagleman \& McNary, 2010).

The interdisciplinary nature of sport management has spearheaded discussion about its appropriate home (Chalip, 2006; Costa, 2005). Even within the HPER umbrella, sport management can be housed in a diverse array of academic units, from recreation (Sawyer, 1993) and sports studies to public health (Sawyer, 1993; Boucher, 1998; Inoue \& Berg, 2014). In contrast, other scholars have laid the groundwork for a closer connection to management-related disciplines. Chelladurai (1992, p. 217) stated that "our game is management," while Slack (1998) argued that sport management would best fit under the organizational behavior field of a business school. According to Danylchuk and Boucher (2003), sport management could shift from a human movement foundation to a business orientation, because the sport management field is not appreciated by kinesiology and physical education programs, and has closer academic connections to business than kinesiology. In response to growing concerns by leading industry executives that more focus should be placed on business fundamentals rather than sports-themed courses, the University of Oregon established the first endowed sports business program in the Lundquist College of Business at the Warsaw Sports Marketing Center in 1993 (Warsaw \& Swangard, 2004). Since then, the number of sport management programs (including majors, minors, and certificates) housed in a school of business, or with formal curriculum-based ties to a school of business (hereinafter sport business programs), has grown to over 200 programs in the U.S. (Li et al., 2013).

In light of this growth, sport management has the potential to shift to a more business-oriented discipline (Danylchuk \& Boucher, 2003; Jones et al., 2008; Schwarz, 2010). Sport management may be reaching a necessary critical mass of programs and a higher level of acceptance within the business academe, similar to now mainstream business subdisciplines such as entrepreneurship and international business, which also underwent a period of transition and broad acceptance (Chalip, 2006; Katz, 2008; Shenkar, 2004).

However, there is a lack of empirical research on sport business programs, including research on interdisciplinary programs featuring faculty and resources shared among different units or even among (and within) business school departments. No benchmark data are available to institutions contemplating movement to or establishment of a sport management program in a school of business. Thus, the purpose of this study was to survey department chairs and program directors employed in U.S. business schools offering sport business programs to provide, for the first time, benchmarking information on the state of sport business programs. Further, this investigation assesses distinctive issues critical to decision makers, such as educational background of administrators and faculty in such programs, sport business programs' positioning in business school units, accreditation, faculty loads, research expectations of faculty, and salary data on faculty and alumni.

\section{Key Issues in Sport Business Program Development}

\section{Accreditation.}

Sport business programs need to consider broader business accreditation considerations and operate under the overarching institutional effort to maintain business accreditation, which is a key value-adding proposition for the future of business schools (Noorda, 2011). Business accreditation offers perceived benefits such as accountability for program improvements, recognition as a superior institution, increased bargaining leverage for university resources, and increased program attractiveness when recruiting (Roller, Andrews \& Bovee, 2003; Tullis \& Camey, 2007). Three of the most successful professional organizations in the U.S. that have made the most of the growing market for business schools' accreditation are the Association to Advance Collegiate Schools of Business (AACSB), the Accreditation Council for Business Schools and Programs (ACBSP), and the International Assembly for Collegiate Business Education (IACBE) (Brink \& Smith, 2012). The AACSB is currently regarded as the "gold standard" because it has higher perceived selectivity, service, quality, and brand image than both the ACBSP and IACBE (Iossifova, 2008; Roller et al., 2003). The AACSB typically reviews most research-oriented business schools in the U.S. and accredits a business school in its entirety, whereas ACBSP and IACBE accredit certain programs housed in business schools, which usually have a teaching focus (Brink \& Smith, 2012).

Unlike most programs in most business schools, sport management programs appeared externally deficient due to the lack of a formal accreditation process before the arrival of the Commission on Sport Management Accreditation (COSMA) in 2008 (Gladden \& Williams, 2012). COSMA launched an outcome-based, missiondriven specialized accreditation model (Williams \& Colles, 2009), but it has gained limited traction, as only $15 \%$ of all sport management programs are institutional members of COSMA ("Commission on Sport Management Accreditation," n.d.; Gladden \& Williams, 2012). Questions exist regarding the broader need for accreditation within the sport management discipline, as well as the feasibility and efficiency of an accreditation 
mandate (Fielding et al., 1991; Williams \& Colles, 2009). Accreditation efforts require the participation of the stronger programs and people for successful implementation as well as the acceptance of professionals in the sports business community (Cuneen, 2004; Gladden \& Williams, 2012; Mahony, 2008). However, with a growing number of high quality programs embedded in business schools (Li et al., 2013; Warsaw \& Swangard, 2004), such programs may consider the COSMA accreditation redundant because they are housed in business school units, which are already accredited by a more visible and established accrediting agency (Gladden \& Williams, 2012; Jones et al., 2008).

\section{Faculty Performance Requirements.}

Deans and promotion and tenure committees at researchoriented business schools are not usually impressed by a publication record solely in a sport-related academic journal (Fink \& Barr, 2012; King, 2013). However, sportfocused faculty may find it difficult to publish sport research in high-quality parent disciplines' journals (Shilbury, 2011). In fact, sport scholars have inquired whether there is a respect issue or a research focus issue in academic business journals, or a perceived quality issue with sport management researchers (Inglis, 2007; Mahony \& Pitts, 1998; Shilbury \& Rentschler, 2007). Despite quality perceptions by business journals' constituents and strategic publication challenges, several sport researchers will want to contribute to mainstream business journals (Danylchuk \& Boucher, 2003; Shilbury, 2011), and sport management and marketing research may conceivably be gaining traction in top business journals, particularly in the generic marketing journals (Shilbury, 2011). This could be a matter of research specialization, as studies indicated that one of the major areas in sport scholarly research is sport marketing (Ciomaga, 2013; Dittmore, Mahony, Andrew, \& Phelps, 2007). Moreover, to further support the momentum of sport management research in the business academic community, the American Marketing Association added a section on sport marketing, and the Academy of Marketing Science (AMS) has partnered with Sport Marketing Quarterly to award a best paper in sport marketing (Academy of Marketing Science, 2013).

\section{Faculty Salaries.}

According to salary survey reports from AACSB (2013a), new assistant professors in marketing or management, and new assistant professors in finance within U.S. business schools are earning on average over $\$ 110,000$ a year, and over $\$ 140,000$ a year, respectively, while eight years ago salaries for assistant professors in U.S. sport management programs started at \$50,001-\$55,000 (Mahony, Mondello, Hums, \& Judd, 2006). However, one should also note that there is no recent salary data for U.S. sport management faculty, and the sport management academic field lacks sport management-specific and sport business-specific salary surveys. Those in the sport management professoriate, who are experts in a particular field related to a business root discipline, may choose to work only with programs that are housed within a school of business because a competitive salary in the sport management field is important to attract or retain a valuable faculty member (Mahony et al., 2006). However, a business school may employ a market-driven salary approach, and given the rather low salaries in the U.S. sport industry (King, 2009), sport management faculty employed in a business school may have lower salaries compared with other business faculty (Fink \& Barr, 2012). On the other hand, sport management professors who can also teach in the business parent disciplines may command higher salaries (Association to Advance Collegiate Schools of Business [AACSB], 2013a).

\section{Alumni Salaries.}

Business schools are sometimes reluctant to integrate or launch sport programs because business school rankings are based in part on their graduates' starting salaries (Fink \& Barr, 2012). The average starting salary for a sport management major was $\$ 37,000$ in 2014 , while other business majors had higher starting salaries (i.e., supply chain management, $\$ 52,800$; finance, $\$ 49,200$; accounting, \$45,300; marketing management, \$42,100) (PayScale, 2014). In fact, salary disparity for recent graduates was one of the reasons cited for the elimination of the sport business program at Arizona State University (Fink \& Barr, 2012). However, graduates with business degrees earned more on average than those with sport management degrees at all levels within sport organizations (King, 2012). Another issue to consider is the fact that business graduates can apply for and obtain sport management jobs, thus potentially cannibalizing sport management students' jobs (Danylchuk \& Boucher, 2003; King, 2009).

\section{Method}

\section{Participants and Data Collection}

The questionnaire was initially assessed and refined by three academic experts in the sport business field and followed by two pilot studies to revise the clarity, readability, format, and content of the survey (cf. Churchill \& Brown, 2004). These pilot studies were carried out by distributing a web link to the questionnaire to 73 faculty members affiliated with U.S. sport business programs, as a substantial body of research suggested the value of incorporating the insights of persons who are being studied (cf. Chalip, 1997; Inglis, 2007). The survey was refined according to feedback from the first panel and then pilot-tested with a second set of academics $(N=38)$ for overall readability, clarity, and flow. The final questionnaire was developed based on the results of the pilot studies.

The study's population consisted of 228 U.S. sport business programs identified by searching the website of each business school member of AACSB, ACBSP, and IACBE accrediting agencies in the U.S., and by collecting available information for each sport business program. These agencies were selected based on the fact that they 
accredit the vast majority of U.S.-based business schools (Brink \& Smith, 2012). The authors completed this task over the course of a five-year study by examining U.S. accredited business schools' websites; interrater agreement on the identified U.S. sport business programs was greater than $80 \%$, and all instances of intercoder disagreements were discussed and resolved (cf. Lombard, Snyder-Duch, \& Bracken, 2002).

A message containing a link to a web-based survey was distributed via e-mail to the surveyed subjects. In the message and in the survey individuals were advised to complete the survey only if their position title was that of a department chair or program director of a sport business program. Moreover, if the respondents did not hold the above professional position, they had the option to provide the e-mail address of the person responsible for the sport business program and then end the survey.

Three follow-up invitations were sent, and the survey remained active for 16 weeks after the initial questionnaire was distributed, upon which time a total of 88 surveys were collected. Incomplete information eliminated 14 surveys, which resulted in 74 usable surveys and a $32.46 \%$ response rate. Research in the social sciences has shown that the overall response rate for web-based surveys is approximately 33\% (Nulty, 2008; Watt, Simpson, McKillop, \& Nunn, 2002), and thus confirming the appropriateness of the current sample.

The survey software allowed just one response to be recorded from each IP address, preventing participants from taking the survey multiple times. The population data of U.S. sport business programs $(N=228)$ was compared against the sample of data collected $(N=74)$. No significant difference between the population and the sample was found in terms of type of degrees offered, business accreditation agencies, and institution type (i.e., public/private). The demographic characteristics of the respondents are profiled in Table 1.

$\backslash$ Insert Table $1 \backslash$

\section{Data Analysis}

Data were analyzed using Statistical Package for the Social Sciences (SPSS) 21 and Stata 12. The researchers examined the data for effects associated with U.S. business schools' accreditation bodies: AACSB $(n=29)$, ACBSP $(n=21)$, and IACBE $(n=24)$ because previous research recognized that $\mathrm{AACSB}$, ACBSP, and IACBE differ with respect to the rigidity and rigor of their accreditation guidelines and with respect to teaching, research, and allocation of resources in a business school (Brink \& Smith, 2012; Hedrick, Henson, Krieg, \& Wassell, 2010; Li et al., 2013; Roller et al., 2003). Therefore, the researchers used descriptive statistics to analyze characteristics of chairs/program directors and their sport business programs, considering these three accreditation agencies. Their views are important, as the role of department chairs and program directors is crucial for the success of an educational institution and program, given that $80 \%$ of university decisions are made at the department or program level (Hecht, Higgerson, Gmelch, \& Tucker, 1999; Wolverton, Gmelch, Wolverton, \& Sarros, 1999). The descriptive statistics, although suggestive in terms of determining guidelines for sport business programs and potential impact for educational institutions, did not adequately assess the degree of explaining the different possible outcomes of business accreditation of U.S. sport business concentrations. Therefore, the study also employed a multinomial logit regression analysis to assess which key characteristics would explain the business accreditation of U.S. sport business programs.

Because this article used a dependent variable with three different categories, this study estimated a multinomial logit model, which permits the analysis of decisions across more than two categories in the dependent variable. The "AACSB" category served as the reference group, because the reference group should act as a useful comparison and the baseline group should not have a small sample size relative to the other groups (Cohen, Cohen, West, \& Aiken, 2003). The independent variables were collected as continuous or categorical variables (Cohen et al., 2003). For a full list on how the independent variables were measured, see Table 2 and Table 3 .

\section{$\backslash$ Insert Tables 2 and $3 \backslash$}

Spicer (2005) proposed that a minimum sample size of 100 is needed to establish a logit regression model. However, this study examined the marginal effects of the explanatory variables on the probabilities of each professional business accreditation level, since marginal effects greatly simplified the analysis (Cameron \& Trivedi, 2009; Gallié \& Roux, 2010), and because marginal effects are robust even with sample sizes of 50 cases (Bergtold, Yeager, \& Featherstone, 2011). Marginal effects were interpreted as the effect on the conditional mean of the dependent variable of a change in one of the independent variables (Cameron \& Trivedi, 2009).

\section{Results}

\section{Profile of U.S. Sport Business Programs}

The AACSB-accredited institutions accounted for 89 of the 228 U.S. sports business programs used as the population for this study, followed by ACBSP $(n=71)$ and $\operatorname{IACBE}(n=68)$. Undergraduate programs were housed at 205 institutions and 59 institutions housed graduate programs, whereas 36 housed both. With respect to the type of degree being offered, majors were offered at 136 institutions, followed by concentrations $(n=87)$, minors $(n=39)$, certificates $(n=22)$, and tracks or specializations $(n=9)$. With respect to COSMA accreditation, seven institutions were accredited by COSMA, while seven have reached candidate status and five have become institutional members. 


\section{Preliminary Analyses}

All independent variables were checked for multicollinearity using bivariate correlations. All correlation coefficients were equal to or below the suggested threshold of .9 (Tabachnick \& Fidell, 2007). However, the examination of variance inflation factor values in the multinomial logit regression analysis revealed that the "department's administration allocation" variable exceeded a cutoff of 10 (Belsley, Kuh, \& Welsch, $1980)$ and was therefore excluded from the analysis.

\section{Descriptive Statistics}

\section{Participants.}

Differences were identified in regard to the participants' highest level of education degree major, as the majority of the AACSB- and IACBE-sport business programs' department chairs and program directors graduated with a business-related degree major, whereas the majority of the ACBSP-sport business programs' chairs and directors graduated with a sport management-related degree major. Moreover, the majority of IACBE-sport business programs' department chairs and program directors were on a nontenure track and their highest level of education were master's and doctoral degrees, while the majority of the AACSB- and ACBSP-sport business programs' chairs and directors were already tenured and their highest level of education were doctoral degrees.

Table 2 and 3 present the percentages, means and standard deviations of sport business programs' characteristics by business accrediting agencies.

\section{Sport Program Department.}

As presented in Table 2, 68.92\% of sport business programs were part of an interdisciplinary department/program. Furthermore, $95.95 \%$ of sport business programs were fully integrated with their business schools. Differences occurred in regard to educational institutions' type in terms of funding source and with respect to Carnegie classification. The preponderance of the ACBSP- and IACBE-sport business programs were part of private educational institutions and were classified as Comprehensive/Master's granting or Teaching/Baccalaureate granting institutions according to the Carnegie classifications, whereas the majority of AACSB-sport business programs were accommodated in public educational institutions and were classified as research universities according to the Carnegie classifications (see Table 2). Consequently, the research allocation of sport business programs' faculty was higher on average for the AACSB-sport business programs, compared with the ACBSP- and IACBE-sport business programs (see Table 3 ).

\section{Sport Program COSMA Interest.}

Fifty percent of sport business programs' department chairs or program directors acknowledged they are not interested in pursuing accreditation from COSMA (see Table 2). When chairs and directors were asked to elaborate on their sport business programs' noninterest in
COSMA, $56.10 \%$ of them stated their sport business program accomplishes the same goals as COSMA's (e.g., quality measures, teaching excellence, etc.) by both internal processes and external business accrediting agencies reviews. Furthermore, $26.83 \%$ of chairs and directors chose other reasons for their COSMA noninterest, such as time constraints and COSMA accreditation costs, whereas $17.07 \%$ of chairs/directors asserted there is no value for COSMA in a sport-related program housed in a business school. Compared with COSMA accreditation noninterest, sport business programs which were COSMA-accredited or pursuing accreditation were in the minority for this sample. When chairs and directors were asked to elaborate why they considered COSMA accreditation valuable, $30 \%$ of them stated there is value for their sport business program from the peer-review COSMA has introduced, and also 30\% of chairs/directors affirmed their sport business program needs and trusts external input from other sport management faculty for their sport business programs' growth. Moreover, $26.67 \%$ of chairs and directors chose other reasons for their COSMA interest, such as provost's requirements and marketing differentiation in the sport management academic field, while $13.33 \%$ of chairs declared that measures of teaching excellence and students' learning that COSMA provides are not available through other accrediting agencies.

\section{Teaching Load.}

Several results are worth noting. First, two to four class sections per year signified the majority of the AACSBsport business programs' usual teaching load for a tenuretrack faculty member without administrative responsibilities, while seven or more class sections per year indicated the preponderance of the ACBSP- and IACBE-sport business programs' usual teaching load for a tenure-track faculty member without administrative responsibilities (see Table 2). The average student-faculty ratio was 39.36 at the undergraduate level and 14.67 for graduate courses with very little variation across the three accrediting agencies (see Table 3 ).

\section{Faculty Performance Measures.}

An academic journals' list was maintained by $31.08 \%$ of the institutions. However, differences were detected regarding the maintenance of an academic journals' list for the purposes of promotion, tenure, or annual reviews among programs in business schools carrying different accreditations: The majority of AACSB-sport business programs had an academic journals' list, while the ACBSP - and IACBE-sport business programs did not. Furthermore, most of the ACBSP- and IACBE-sport business programs' faculty did not have a minimum number of academic publications required for tenure, while $20.69 \%$ of AACSB-sport business programs' faculty were required to publish more than six academic manuscripts in consideration of tenure (see Table 2). When chairs and directors were asked about the sportrelated academic journals included in the academic journals' list at the top level/tier, the following sport- 
related journals were selected: Journal of Sport Management, 16; Sport Marketing Quarterly, 12; Sport Management Review, 6; Sociology of Sport Journal, 4; European Sport Management Quarterly, 3; Journal of Legal Aspects of Sport, 2; and Journal of Sport Economics, 2. Moreover, eight U.S. sport business programs (i.e., AACSB-sport business programs) had a journals' list specific to business-based journals, 10 programs had an interdisciplinary academic journals' list, while five other programs had a journals' list specific to sport-based journals.

New Faculty Hires and Salaries.

As presented in Table 2, the AACSB-sport business programs reported higher salaries for every faculty level (i.e., lecturer/instructor/visiting professor, assistant professor, and associate/full professor), compared with the ACBSP - and IACBE-sport business programs. Salary ranges were collected rather than exact salaries because past research has shown that respondents tend to be more willing to divulge salary ranges (cf. Parks \& Bartley, 1996). Furthermore, there were 78 reported new hires (i.e., over the past five years) in total: 43 new hires for a new position, and 35 new hires for a replacement. Regarding the tenure status for those 78 new hires, there were 40 new hires for a tenure-track position, and 38 new hires for a non-tenure-track position. Moreover, the degrees of the new hires' highest level of education were completed in sport management, 31; business, 16; education, 5; law, 5; and other disciplines, 3. At the tenure-track level, the degrees of the new hires' highest level of education were earned in sport management, 22; business, 6; education, 3; law, 3; and other disciplines, 2.

\section{Alumni Salaries.}

Respondents reported the average starting salary for alumni was $\$ 31,788(S D=\$ 6,337.99)$ for undergraduate alumni and $\$ 45,000(S D=\$ 11,516.29)$ for graduate alumni. IACBE-sport business programs graduate alumni's starting salaries per year were higher than the other two business accrediting agencies' sport business programs; however, there were only three reported salaries in the IACBE-sport business programs graduate alumni's starting salaries per year (see Table 3).

\section{Multinomial Logit Regression Analysis}

The likelihood ratio chi-square test to measure goodness of fit was significant, $\chi^{2}(24)=55.68, p<.001$, which indicated that the full model did predict significantly better, or more accurately, than the null model. In addition, the independence of irrelevant alternatives hypothesis was not violated based on the Hausman-type test (Hausman \& McFadden, 1984).

The dependent variable defined $34.52 \%$ of the variance in independent variables according to McFadden value (McFadden, 1974).

A full representation on marginal effects of the multinomial logit regression analysis can be viewed in Table 4 . The probability of a sport business program being housed in a school of business from the "AACSB" business accreditation category was significantly reduced by an increase in the usual teaching load within a sport business program for a tenure-track faculty member $(d y / d x=-.273, p=.005)$. Moreover, the probability of a sport business program being housed in a school of business from the "AACSB" business accreditation category was significantly reduced by a decline in the percentage of the sport business program's research allocation for their faculty seeking tenure $(d y / d x=.027, p$ $=.001)$.

\section{$\backslash$ Insert Table $4 \backslash$}

The probability of a sport business program being housed in a school of business from the "ACBSP" business accreditation category was significantly reduced by a decline in the usual teaching load within a sport business program for a tenure-track faculty member $(d y / d x=.279, p<.001)$. Finally, the probability of a sport business program being housed in a school of business from the "IACBE" business accreditation category was significantly reduced by an increase in the percentage of the sport business program's research allocation for their faculty seeking tenure $(d y / d x=-.018, p=.009)$.

\section{Discussion and Implications}

This study sought to survey department chairs and program directors employed in business schools housing sport management programs to provide, for the first time, benchmarking information on trends and key issues of sport business programs. Despite a growing interest in assessing the evolution and future of sport business programs, no researchers have pursued an empirical investigation on this particularly important topic ( $\mathrm{Li}$ et al., 2013), highlighting the significance of this inquiry.

\section{Sport Business Programs' Growth and Administrators' Educational Background}

Thirty sport management programs were housed in business schools in 2000 (Rosner, Mayo, McCarthy, \& Fay, 2000), signifying now, with the identified 228 U.S. sport business programs, considerable growth in business school-housed sport business programs.

More AACSB and ACBSP chairs and programs directors had a terminal degree than IACBE chairs and program directors; therefore, the fact that more IACBE chairs/directors were on a nontenure status appears logical. Our findings partly contradict previous business research where only academic programs with AACSB accreditation had the majority of terminal degrees (Corcoran, 2007). At the same time, one can argue that more ACBSP programs appear to make a consistent effort toward hiring $\mathrm{PhDs}$ in particular, and at least several of such ACBSP programs have communicated a desire by their administrators to eventually pursue AACSB accreditation (B. Knebel, personal communication, April 
11, 2014). This lack of a terminal degree from IACBE chairs and program directors may contribute to the shortage of external funding received by an academic department (Jones et al., 2008) and can also affect the future of sport business programs. As IACBE-sport business programs are managed and taught by nontenured faculty, problems may arise in terms of job security and turnover among sport business programs.

Moreover, the lack of foreign-born chairs/program directors, corroborated with having the highest level of education's degree location almost solely in United States (see Table 1), can have a negative impact for the global growth of U.S. sport business programs. Academic programs need a new source of talent (Mahony, Mondello, Hums, \& Judd, 2004), and there are consistent efforts by U.S. higher education institutions to recruit internationally, primarily from developing markets, to boost their bottom line and engage in global outreach, which may lead to maintenance of consistent international pipelines (Institute of International Education, 2014). Such global outreach is required not only for teaching globalization of sports (Danylchuk \& Boucher, 2003), but also for a better understanding of global aspects and the growth of sports business internationally. Hence, U.S. business schools will be able to better manage their growing internationalization (de Onzoño \& Carmona, 2007) and, implicitly, the internationalization of their sport business programs.

\section{Housing Unit}

Sport researchers argued for interdisciplinarity as a natural tendency to work across academic units, and disapproved the silo mentality that can be present in the sport management academic field (Amis \& Silk, 2005; Chalip, 2006; Costa, 2005; Doherty, 2012; Mahony, 2008). This study's results recognized that the majority of U.S. sport business programs were part of an interdisciplinary department and were well integrated in business schools. As more than $13 \%$ of the surveyed U.S. sport business programs reported having an interdisciplinary journals' list, this interdisciplinarity may help enlarge the breadth of sport management research, which ultimately may become more recognized and valued by other academic disciplines (Costa, 2005; Mahony, 2008). Analogous with previous business research (cf. Brink \& Smith, 2012), public and Research institutions (Carnegie Foundation for the Advancement of Teaching, n.d.) were more likely to have AACSB-accredited sport business programs, while private institutions and Comprehensive/Master's granting or Teaching/Baccalaureate granting institutions (Carnegie Foundation for the Advancement of Teaching, n.d.) were more likely to have ACBSP- or IACBE-accredited sport business programs. Thus, students, faculty, and administrators, who contemplate movement to a school of business, can have a better understanding of what accredited sport business programs offer in terms of funding and research/teaching capabilities.

\section{COSMA vs. Business Accreditation}

Regarding the sport business programs' COSMA interest, this research empirically assessed for the first time what past sport research theorized (Gladden \& Williams, 2012; Jones et al., 2008): The majority of surveyed department chairs and program directors of U.S. sport business programs view the COSMA accreditation as redundant. Because sport business programs are housed in academic units that are already accredited by more visible accrediting agencies such as AACSB, ACBSP, and IACBE, acceptance and recognition of COSMA accreditation is an issue. Moreover, only $8.33 \%$ of the U.S. sport business programs from this study's population are COSMA accredited or pursuing this accreditation. COSMA accreditation was founded due to credibility issues in the sport management field, due to problems with academic acceptance from other departments and colleges, as well as problems such as lack of basic curriculum and research competencies (Case, 2003; Cuneen, 2004; Cuneen \& Sidwell, 1998; Mahony, 2008; Williams \& Colles, 2009). As sport management programs migrate to business schools, these credibility issues most probably begin to subside. However, it will be interesting to see if COSMA-accredited sport management programs wishing to establish themselves in business schools will want to maintain COSMA accreditation. It appears logical for the board of directors of COSMA to minimize the reasons for COSMA noninterest and take full advantage of the motivations behind having a COSMA-accredited sport business program.

Further, it seems that IACBE has less rigid accreditation principles, on par with previous studies (cf. Brink \& Smith, 2012), as evidenced by the fact that nearly $42 \%$ of IACBE-accredited sport business programs have chairs/directors on a nontenure track and over $37 \%$ of IACBE-accredited sport business programs are pursuing COSMA accreditation.

\section{Faculty Load}

AACSB-sport business programs' usual teaching load was, on average, considerably lower than the ACBSPand IACBE-sport business programs' usual teaching load for a tenure-track faculty member without administrative responsibilities. Moreover, the findings suggest that ACBSP-sport business programs reported significantly higher teaching loads than AACSB-sport business programs. This outcome is most probably due to the fact that ACBSP accreditation standards are more teaching oriented than AACSB accreditation standards (Hedrick et al., 2010; Roller et al., 2003). High teaching loads can have a negative impact on both teaching and research because professors will have less time to spend preparing the classes and less time to produce quality research (Mahony et al., 2004).

The results also recognized that AACSB-sport business programs set significantly higher research expectations for their faculty seeking tenure than the IACBE-sport business programs. Moreover, past research 
discussed the trade-off between teaching and scholarship, suggesting that schools that place a higher emphasis on research will have lower scores for teaching (Iossifova, 2008). However, AACSB adopted mission-oriented accreditation standards, making it possible for teachingoriented institutions to receive accreditation (Henninger, 1998; Jantzen, 2000). AACSB also features a percentage of business schools that are teaching oriented, and the descriptive results in Table 3 show that the majority of AACSB-sport business programs' tenure allocation is in teaching. AACSB schools and, implicitly, their sport business programs may be better positioned for the future than ACBSP - and IACBE-sport business programs, because there is a big difference in the tenure allocation between teaching and research in ACBSP- and IACBEsport business programs (see Table 3). It is the researchers' opinion that teaching and research should be emphasized in an equal manner as sport business programs need not only groom future leaders of the sport business industry, but also produce high-quality scholarship of industry relevance for the advancement of the sport management academic field.

\section{Research and the Sport Business Discipline}

The findings suggest that AACSB-sport business programs reported a significantly higher research allocation than the IACBE-sport business programs. Moreover, on average, the AACSB-sport business programs' research considerations, including having an academic journals' list and a required number of scholarly publications for tenure, had higher values than the ACBSP - and IACBE-sport business programs. AACSB is perceived as promoting excellence in research compared with the other two business accrediting agencies (cf. Roller et al., 2003; Brink \& Smith, 2012). The research allocations of the ACBSP - and IACBEsport business programs are mostly overlapping (see Table 3), with slightly higher average values for ACBSPsport business programs - most probably due to the fact that ACBSP's scholarship guidelines could be regarded as more rigorous given that they are standards rather than principles (Brink \& Smith, 2012). Thus, professors and doctoral students wishing to have more of a research career than a teaching career would be better served pursuing employment at an AACSB-sport business program, because the focus on research is consistent with the demands of search committees at research institutions (Mahony, Mondello, Hums, \& Judd, 2004).

Interestingly, there were eight AACSB-sport business programs (i.e., 27.59\% of AACSB-sport business programs in the sample), that did not have any sport-related journals included in their prescribed academic research journal list. Danylchuk \& Boucher (2003) stated that research contributions to mainstream business journals was rated by sport scholars medium in terms of probability and high in desirability, and acknowledged that more exposure to journals outside sport management might increase the credibility of the field. However, other than sport marketing research
(Shilbury, 2011), predominant business journals in parent disciplines do not feature sport-related research, indicating a problem and continuous obstacles researchers in such AACSB-accredited institutions will need to overcome, primarily by means of introducing at least a few sportspecific journals either in existing journal lists or by developing new interdisciplinary lists capturing quality research outlets.

In addition, sport management may be evolving as its own distinct discipline, as evidenced by the number of professional organizations and journals supporting the field, the number of academic programs worldwide, and an increasing number of dedicated scholars pursuing sport management-related teaching and research (Shilbury \& Rentschler, 2007). Moreover, whether there can be theory that is specific and exclusive to this field has been debated, with consistent arguments in favor and evidence of what may be unique about sport (Doherty, 2013).

\section{Sport Business Faculty and Salaries}

Regarding salaries for new hires, as anticipated, the majority of AACSB-sport business programs reported higher salaries compared with the ACBSP- and IACBEsport business programs. The latter programs are more in line with assistant professors' salary findings of Mahony and colleagues (2006). The salary gap between AACSB faculty and ACBSP and IACBE faculty is also confirmed by previous business studies (cf. Brink \& Smith, 2012). Moreover, comparing salary survey reports from AACSB (2013b), ACBSP (2012), and IACBE (Brink \& Smith, 2012) for professors in more established academic areas in business schools (i.e., marketing, management, finance, etc.), all sport business programs' professors salaries were relatively close to the salary ranges of management and marketing professors, but below the salary ranges for finance professors. Considering that a competitive salary in the sport management field is important to attract or retain a valuable faculty member (Mahony et al., 2006), AACSB-sport business programs can have a competitive advantage.

On the field's overall progress and growth, the data collected tell quite a story, considering that more than $60 \%$ of institutions hired at least one new faculty member over the past five years. The majority of the new hires' highest level of education is in sport management, which arguably confirms that the academic field has gained respect in U.S. business schools, in contrast to arguments made by sport scholars who discussed the lack of credibility experienced by sport management faculty (cf. Chalip, 2006; Mahony, 2008). Given the results of this study, particularly on salaries and faculty educational backgrounds, one may argue that sport management was never at a better position in regard to acceptance within schools of business. However, another explanation could be that there is a shortage of qualified business school educators, and U.S. business schools are urged to seek professors from other academic disciplines to fill out faculty positions (cf. David, David, \& David, 2011), such as sport management. Regardless, it seems that the 
demand for sport management professors is strong (cf. Mondello, Mahony, Hums, \& Moorman, 2002; Weese, 2002 ), as $55.13 \%$ of the open faculty positions were for a new position. In addition, faculty turnover seems to have kept the same high values from more than a decade ago (cf. Mondello et al., 2002); however, there is less mobility for those professors at the rank of associate or full professor (see Table 2) as the majority of new faculty positions at U.S. sport business programs are entry level (i.e., lecturer, instructor, visiting professor, and assistant professor).

\section{Alumni Salaries}

Another important finding is the sport business programs alumni's starting salary. Across all three accrediting agencies' sport business programs annual average starting salaries had low variability (between $\$ 29,000-34,000$ ), in line with past estimates on sport management majors' average starting salary of approximately $\$ 30,000$ (King, 2009). These figures are below the average starting salary of $\$ 37,000$ that PayScale reported (2014). Furthermore, considering that business majors' average starting salary is $\$ 55,635$ according to the National Association of Colleges and Employers (2013), undergraduate and graduate students in sport business programs are well below business majors' average, even though chairs and program directors reported that more than $39 \%$ of U.S. sport business programs' alumni take general businessrelated jobs. Therefore, low salaries for entry-level positions for sport business graduates could turn prospective students to a general business degree instead of a sport business degree. It is interesting to note that while alumni salaries remain fairly stagnant and low compared with other business school graduates, the salaries of sport management professors in sport business programs have grown closer to U.S. business schools' faculty average salaries, which are considerably higher than nonbusiness professors.

Previous research pointed out the advantage of sport business programs recruiting students, who consider applying to (nonbusiness school) sport management programs (Danylchuk \& Boucher, 2003). Given our findings on sport business alumni salaries and also considering that frequently the cost of a nonbusiness sport management degree may be substantially lower, sport business programs may be challenged to entice students, who would consider attending an otherwise established sport management program, albeit outside a business school. Indeed it appears that entry-level salaries are low across the board, be it for sport business or sport management (nonbusiness) alumni. If it is true, however, that sport practitioners prefer a business-related emphasis for their entry-level hires (Parkhouse, 1996; Petersen \& Pierce, 2009), industry demand could give sport business graduates a competitive edge. Moreover, these sport business graduates may always choose to work in the general world of business (Fink \& Barr, 2012; King, 2009).
A problem that can arise is that many business schools are ranked based on graduates' starting salaries; therefore, business schools can be reluctant to integrate or launch sport programs because of the low average starting salary (Fink \& Barr, 2012). Various ways to increase sport business alumni's salaries include "following the money" and encouraging sport business alumni to pursue generalbusiness jobs or sport jobs that currently have high demand, such as analytics. Due to the increasing demand of analytics in the sports industry (Sutton, 2013), and because qualified data analysts/scientists can command impressive six-figure salaries right out of school (Burtch Works, 2013; Morris, 2013), administrators of U.S. sport business programs would be well served to address this demand.

\section{Limitations and Future Research}

Even though this research has provided important insights to the continued understanding of sport business programs, it also has some limitations. These limitations can be excellent starting points for future research.

First, whereas this research was developed within the U.S. context, it might not be applicable to other countries. Thus, researchers should test these findings in more countries and regions where sport business programs have experienced growth, such as Australia, Canada, the United Kingdom, and continental Europe. Second, while the samples collected were acceptable for the research questions scrutinized in the current study, larger samples would augment the soundness of the current study. Third, although this research analyzed important sport business programs issues, it did not measure the probably valuable perceptions of general business faculty about their business schools' sport business program (Li et al., 2013). Fourth, future studies should also take into account the challenges of sport management programs that are not yet housed in a business school and are willing to align themselves with their business school. Fifth, the study did not report on potentially important topics, such as the sport business programs' benefits of being housed in a school of business, and the key areas that led to sport programs being accepted into their institutions' business schools; future research should take into account these research ideas. Sixth, the researchers searched the website of each business school member of AACSB, ACBSP, and IACBE accrediting agencies in the U.S. for sport business programs, but there is the possibility that the information available in the U.S. business schools' websites is not upto-date; thus, there is a chance for fewer or additional sport business programs in the study's population.

While the current study does have some limitations, it provides valuable information to be used in assisting business schools and their sport business programs to better impact their stakeholders. Given these results and their broad implications, further investigation into the way sport business programs inform business accreditation and into the evolution of U.S. sport business concentrations is warranted. 


\section{Conclusion}

Sport business programs in the U.S. have come a long way over the past 20 years, since the first sport business program was established at the University of Oregon (Warsaw \& Swangard, 2004). Rosner and colleagues (2000) made known that, worldwide, there were 17 undergraduate sport management programs and 13 graduate sport management programs housed in a business school. Currently, there are more than 200 sport business programs in the U.S. alone according to this manuscript's study population, with the potential for further growth in the years to come (Danylchuk \& Boucher, 2003; Jones et al., 2008; Schwarz, 2010). Current and future sport business programs should consider the various issues of being housed in a school of business, because the future of sport management as an academic discipline is connected with the answers to questions regarding important matters such as administrative oversight, faculty educational backgrounds and performance requirements, accreditation, and fair compensation (Danylchuk \& Boucher, 2003).

\section{References}

Academy of Marketing Science. (2013). Call for papers. Retrieved from http://www.amsweb.org/events/event_details.asp?id $=415636$

Accreditation Council for Business Schools and Programs. (2012). Salary survey report. Retrieved from http://c.ymcdn.com/sites/www.acbsp.org/resource/col lection/A04D586B-B128-4097-A27CDD1B7E857831/ACBSP 2012 Salary Survey Exec utive Report-2.pdf

Alsop, W., \& Fuller, G.F. (2001). Directory of academic programs in sport management. Morgantown, WV: Fitness Information Technology.

Amis, J., \& Silk, M. (2005). Rupture: Promoting critical and innovative approaches to the study of sport management. Journal of Sport Management, 19(4), $355-366$.

Arbaugh, J.B., Godfrey, M.R., Johnson, M., Pollack, B.L., Niendorf, B., \& Wresch, W. (2009). Research in online and blended learning in the business disciplines: Key findings and possible future directions. The Internet and Higher Education, 12(2), 71-87. doi:10.1016/j.iheduc.2009.06.006

Association to Advance Collegiate Schools of Business. (2013a). 2012-2013 Salary survey reports. Retrieved from

http://www.aacsb.edu/publications/datareports/salarys urvey/2012-13.pdf

Association to Advance Collegiate Schools of Business. (2013b). Eligibility procedures and accreditation standards for business accreditation. Retrieved from http://www.aacsb.edu/accreditation/business/standard s/2013/2013-business-standards.pdf

Belsley, D.A., Kuh, E., \& Welsch, R.E. (1980). Regression diagnostics: Identifying influential data and sources of collinearity. New York, NY: John Wiley \& Sons. doi:10.1002/0471725153
Bergtold, J.S., Yeager, E.A., \& Featherstone, A.M. (2011). Sample size and robustness of inferences from logistic regression in the presence of nonlinearity and multicollinearity. Paper presented at the Agricultural \& Applied Economics Association's AAEA \& NAREA Joint Annual Meeting, Pittsburgh, Pennsylvania.

Boucher, R.L. (1998). Toward achieving a focal point for sport management: A binocular perspective. Journal of Sport Management, 12, 76-85.

Brink, K.E., \& Smith, C. (2012). A comparison of AACSB, ACBSP, and IACBE accredited US business programs: An institutional resource perspective. Business Education \& Accreditation, 4(2), 1-15.

Burtch Works. (2013). Salaries for big data professionals. Retrieved

from http://www.burtchworks.com/Burtch Works Study Final.pdf

Cameron, A.C., \& Trivedi, P.K. (2009). Microeconometrics using Stata. College Station, TX: Stata Press.

Carnegie Foundation for the Advancement of Teaching. (n.d.). Classification description. Retrieved from http://classifications.carnegiefoundation.org/descripti ons/basic.php

Case, R. (2003). Sport management curriculum development: Issues and concerns. International Journal of Sport Management, 4, 224-239.

Chalip, L. (1997). Action research and social change in sport: An introduction to the special issue. Journal of Sport Management, 11(1), 1-7.

Chalip, L. (2006). Toward a distinctive sport management discipline. Journal of Sport Management, 20(1), 121.

Chelladurai, P. (1992). Sport management: Opportunities and obstacles. Journal of Sport Management, 6(3), 215-219.

Churchill, G.A., \& Brown, T.J. (2004). Basic marketing research. Mason, OH: Thompson South-Western.

Ciomaga, B. (2013). Sport management: A bibliometric study on central themes and trends. European Sport Management Quarterly, 13(5), 557-578. doi: $10.1080 / 16184742.2013 .838283$

Cohen, J., Cohen, P., West, S.G., \& Aiken, L.S. (2003). Applied multiple regression/correlation analysis for the behavioral sciences. Mahwah, NJ: Lawrence Erlbaum Associates, Inc.

Commission on Sport Management Accreditation. (n.d.). Institutional Members. Retrieved from http://www.cosmaweb.org/institutional-members.html

Corcoran, C.P. (2007). Distinctions among accreditation agencies for business programs. Journal of College Teaching and Learning, 4(9), 27-30 (TLC).

Costa, C.A. (2005). The status and future of sport management: A Delphi study. Journal of Sport Management, 19(2), 117-142.

Cuneen, J. (2004). Managing program excellence during our transition from potential to merit. Journal of Sport Management, 18(1), 1-12.

Cuneen, J., \& Sidwell, M.J. (1998). Evaluating and selecting sport management undergraduate programs. Journal of College Admission, 158, 6-13. 
Danylchuk, K.E., \& Boucher, R.L. (2003). The future of sport management as an academic discipline. International Journal of Sport Management, 4(4), 281-300.

David, F.R., David, M.E., \& David, F.R. (2011). What are business schools doing for business today? Business Horizons, 54(1), 51-62. doi:10.1016/j.bushor.2010.09.001

de Onzoño, S.I., \& Carmona, S. (2007). The changing business model of B-schools. Journal of Management Development, 26(1), 22-32. doi:10.1108/02621710710720059

Degrees in Sports. (n.d.). Search sports degrees. Retrieved from http://www.degreesinsports.com/

Dittmore, S.W., Mahony, D.F., Andrew, D.P.S., \& Phelps, S. (2007). Is sport management research diverse? A five-year analysis of dissertations. International Journal of Sport Management, 8(1), 21-31.

Doherty, A. (2012). "It takes a village:" Interdisciplinary research for sport management. Journal of Sport Management, 26, 1-10.

Doherty, A. (2013). Investing in sport management: The value of good theory. Sport Management Review, 16, 5-11. doi:10.1016/j.smr.2011.12.006

Eagleman, A., \& McNary, E. (2010). What are we teaching our students? A descriptive examination of the current status of undergraduate sport management curricula in the United States. Sport Management Education Journal, 4(1), 1-17.

Fielding, L.W., Pitts, B.G., \& Miller, L.K. (1991). Defining quality: Should educators in sport management programs be concerned about accreditation? Journal of Sport Management, 5(1), 1-17.

Fink, J.S., \& Barr, C.A. (2012). Where is the best "home" for sport management? In A. Gillentine, R. Baker, \& J. Cuneen (Eds.), Critical essays in sport management: Exploring and achieving a paradigm shift (pp. 17-25). Scottsdale, AZ: Holcomb Hathaway, Publishers, Inc.

Gallié, E.P., \& Roux, P. (2010). Forms and determinants of R\&D collaborations: Evidence based on French data. Industry and Innovation, 17(6), 551-576. doi:10.1080/13662716.2010.530838

George, J.F., Valacich, J.S., \& Valor, J. (2005). Does information systems still matter? Lessons for a maturing discipline. Communications of the Association for Information Systems, 16(1), 219-232.

Gladden, J., \& Williams, J. (2012). Sport management accreditation: Why it is an imperative step forward. In A. Gillentine, R. Baker, \& J. Cuneen (Eds.), Critical essays in sport management: Exploring and achieving a paradigm shift (pp. 27-40). Scottsdale, AZ: Holcomb Hathaway, Publishers, Inc.

Hausman, J., \& McFadden, D. (1984). Specification tests for the multinomial logit model. Econometrica, 52(5), 1219-1240. doi:10.2307/1910997

Hecht, I.W.D., Higgerson, M.L., Gmelch, W., \& Tucker, A. (1999). The department chair as academic leader. Phoenix, AZ: Oryx Press.

Hedrick, D.W., Henson, S.E., Krieg, J.M., \& Wassell, C.S., Jr. (2010). The effects of AACSB accreditation on faculty salaries and productivity. Journal of Education for Business, 85(5), 284-291. doi:10.1080/08832320903449543

Henninger, E.A. (1998). Dean's role in change: The case of professional accreditation reform of American collegiate business education. Journal of Higher Education Policy and Management, 20(2), 203-213. doi:10.1080/1360080980200207

Inglis, S. (2007). Creative tensions and conversations in the academy. Journal of Sport Management, 21(1), 1-14.

Inoue, Y., \& Berg, B. (2014). The role of sport management in public health: A critical review. Abstract presented at the North American Society for Sport Management, Pittsburgh, PA.

Institute of International Education. (2014). Economic impact of international students. Retrieved from http://www.iie.org/Research-and-Publications/OpenDoors/Data/Economic-Impact-of-InternationalStudents

Iossifova, A. (2008). Research productivity, teaching relevance, and AACSB accreditation. Quality Management Journal, 15(4), 46-56.

Jantzen, R.H. (2000). AACSB mission-linked standards: Effects on the accreditation process. Journal of Education for Business, 75(6), 343-347. doi:10.1080/08832320009599038

Jones, D.F., Brooks, D.D., \& Mak, J.Y. (2008). Examining sport management programs in the United States. Sport Management Review, 11(1), 77-91. doi:10.1016/S1441-3523(08)70104-9

Katz, J.A. (2008). Fully mature but not fully legitimate: A different perspective on the state of entrepreneurship education. Journal of Small Business Management, 46(4), 550-566. doi:10.1111/j.1540627X.2008.00256.x

King, B. (2009, August 23). New lessons to learn. SportsBusiness Journal. Retrieved from http://www.sportsbusinessdaily.com/Journal/Issues/2 009/08/20090823/Degrees-In-Sports-Business/NewLessons-To-Learn.aspx

King, B. (2012, August 13). What's the payoff in sports. SportsBusiness Journal. Retrieved from http://www.sportsbusinessdaily.com/Journal/Issues/2 012/08/13/In-Depth/Salary-survey.aspx

King, B. (2013, August 12). Can academic research help sports industry? SportsBusiness Journal. Retrieved from

http://www.sportsbusinessdaily.com/Journal/Issues/2 013/08/12/In-Depth/Sports-business-professors.aspx

Kjeldsen, E.K. (1990). Sport management careers: A descriptive analysis. Journal of Sport Management, 4(2), 121-132.

Li, M., Synowka, D., Brown Foster, S., Pegoraro, A., Chen, L., \& Kaburakis, A. (2013). Sport management programs in the business school: A survey of perceptions. Symposium presented at the North American Society for Sport Management, Austin, TX.

Lombard, M., Snyder-Duch, J., \& Bracken, C.C. (2002). Content analysis in mass communication: Assessment and reporting of intercoder reliability. Human Communication Research, 28(4), 587-604. doi:10.1111/j.1468-2958.2002.tb00826.x 
Mahony, D.F. (2008). No one can whistle a symphony: Working together for sport management's future. Journal of Sport Management, 22, 1-10.

Mahony, D.F., Mondello, M.J., Hums, M.A., \& Judd, M.R. (2004). Are sport management doctoral programs meeting the needs of the faculty job market? Observations for today and the future. Journal of Sport Management, 18(2), 91-110.

Mahony, D.F., Mondello, M.J., Hums, M.A., \& Judd, M.R. (2006). Recruiting and retaining sport management faculty: Factors affecting job choice. Journal of Sport Management, 20(3), 414.

Mahony, D.F., \& Pitts, B.G. (1998). Research outlets in sport marketing: The need for increased specialization. Journal of Sport Management, 12(4), 259-272.

Mathner, R.P., \& Martin, C.L. (2012). Sport management graduate and undergraduate students' perceptions of career expectations in sport management. Sport Management Education Journal, 6(1), 21-31.

McFadden, D. (1974). Conditional logit analysis of qualitative choice behavior. In P. Zarembka (Ed.), Frontiers in econometrics (pp. 105-142). New York: Academic Press.

Mondello, M.J., Mahony, D.F., Hums, M.A., \& Moorman, A. (2002). A survey of search committee chairpersons: Candidate qualifications preferred for entry-level tenure track sport management faculty positions. International Journal of Sport Management, 3, 262-281.

Morris, C. (2013, June 5). The sexiest job of the 21st century: Data analyst. $C N B C$. Retrieved from http://www.cnbc.com/id/100792215\#.

National Association of Colleges and Employers. (2013). Salary survey. Retrieved from http://www.naceweb.org/uploadedFiles/Content/static -assets/downloads/executive-summary/2013september-salary-survey-executivesummary.pdf?mainindex-recslide1-salsvexsum$\underline{09132013}$

National Center for Education Statistics. (2013). Digest of education statistics: 2012. Retrieved from http://nces.ed.gov/pubs2014/2014015.pdf

Noorda, S. (2011). Future business schools. Journal of Management Development, 30(5), 519-525. doi: $10.1108 / 02621711111133028$

Nulty, D.D. (2008). The adequacy of response rates to online and paper surveys: what can be done? Assessment \& Evaluation in Higher Education, 33(3), 301-314. doi:10.1080/02602930701293231

Parkhouse, B.L. (1996). Definition, evolution, and curriculum. In B.L. Parkhouse (Ed.), The management of sport: Its foundation and application (pp. 3-12). St. Louis, MO: Mosby Year Book.

Parkhouse, B.L., \& Pitts, B.G. (2001). Definition, evolution, and curriculum. In B.L. Parkhouse (Ed.), The management of sport: Its foundation and application (pp. 2-14). New York: McGraw Hill.

Parks, J.B., \& Bartley, M.E. (1996). Sport management scholarship: A professoriate in transition? Journal of Sport Management, 10(2), 119-130.
PayScale. (2014). College salary report. Retrieved from http://www.payscale.com/college-salary-report2014/majors-that-pay-you-back

Petersen, J., \& Pierce, D. (2009). Professional sport league assessment of sport management curriculum. Sport Management Education Journal, 3(1), 107-121.

Plunkett, J.W. (2014). Plunkett's Sports Industry Almanac 2015. Houston, TX: Plunkett Research, Limited.

Roller, R.H., Andrews, B.K., \& Bovee, S.L. (2003). Specialized accreditation of business schools: A comparison of alternative costs, benefits, and motivations. Journal of Education for Business, 78(4), 197-204. doi:10.1080/08832320309598601

Rosner, S., Mayo, A., McCarthy, L., \& Fay, T. (2000). The application of NASSM program standards and review protocol to business school-based sport management programs: Challenges, ideas and strategies. Panel presentation at the North American Society for Sport Management, Colorado Springs, CO.

Sawyer, T.H. (1993). Sport management: Where should it be housed? Journal of Physical Education, Recreation \& Dance, 64(9), 4-5. doi:10.1080/07303084.1993.10607337

Schwarz, E.C. (2010). The reciprocal and influential connection between sport marketing and management and the sport sciences. International Journal of Sport Management and Marketing, 7(1/2), 33-43. doi:10.1504/IJSMM.2010.029710

Shenkar, O. (2004). One more time: International business in a global economy. Journal of International Business Studies, 35(2), 161-171. doi: $10.1057 /$ palgrave.jibs. 8400074

Shilbury, D. (2011). A bibliometric study of citations to sport management and marketing journals. Journal of Sport Management, 25(5), 423-444.

Shilbury, D., \& Rentschler, R. (2007). Assessing sport management journals: A multi-dimensional examination. Sport Management Review, 10(1), 3144. doi:10.1016/S1441-3523(07)70002-5

Slack, T. (1998). Is there anything unique about sport management? European Journal for Sport Management, 5(2), 21-29.

Spicer, J. (2005). Making sense of multivariate data analysis: An intuitive approach. Thousand Oaks, CA: Sage Publications, Inc. doi:10.4135/9781412984904

Sutton, W.A. (2013, August 12). Industry standouts lead sports into new era of decision-making. SportsBusiness Journal. Retrieved from http://www.sportsbusinessdaily.com/Journal/Issues/2 013/08/12/Opinion/Sutton-Impact.aspx

Tabachnick, B.G., \& Fidell, L.S. (2007). Using multivariate statistics. Boston, MA: Pearson Education.

Tullis, K.J., \& Camey, J.P. (2007). Strategic implications of specialized business school accreditation: End of the line for some business education programs? Journal of Education for Business, 83(1), 45-51. doi:10.3200/JOEB.83.1.45-51

Walsh, J.P., Weber, K., \& Margolis, J.D. (2003). Social issues and management: Our lost cause found. Journal of Management, 29(6), 859-881. doi:10.1016/S0149-2063(03)00082-5 
Warsaw, J., \& Swangard, P. (2004, November 29). From the classroom to the boardroom. SportsBusiness Journal. Retrieved from http://www.sportsbusinessdaily.com/Journal/Issues/2 004/11/20041129/Opinion/From-The-Classroom-ToThe-Boardroom. $\operatorname{asp} \mathrm{x} ? \mathrm{hl}=\mathrm{Opinion} \& \mathrm{sc}=0$

Watt, S., Simpson, C., McKillop, C., \& Nunn, V. (2002). Electronic course surveys: Does automating feedback and reporting give better results? Assessment \& Evaluation in Higher Education, 27(4), 325-337. doi:10.1080/0260293022000001346

Weese, W.J. (2002). Opportunities and headaches: Dichotomous perspectives on the current and future hiring realities in the sport management academy. Journal of Sport Management, 16(1), 1-17.

Williams, J., \& Colles, C. (2009). Specialized accreditation of sport management programs: Perspectives of faculty and administrators. Sport Management Education Journal, 3(1), 26-46.

Wolverton, M., Gmelch, W.H., Wolverton, M.L., \& Sarros, J.C. (1999). Stress in academic leadership: U.S. and Australian department chairs/heads. Review of Higher Education, 22, 165-185. 
Table 1 Demographic Characteristics of Respondents $\left(N_{\mathrm{AACSB}}=29 ; N_{\mathrm{ACBSP}}=21 ; N_{\mathrm{IACBE}}=\right.$ 24)

\begin{tabular}{|c|c|c|c|}
\hline \multirow[b]{2}{*}{ Demographic Variable } & \multicolumn{3}{|c|}{ Business Accrediting Agency } \\
\hline & AACSB & ACBSP & IACBE \\
\hline \multicolumn{4}{|l|}{ Gender } \\
\hline Male (\%) & 68.97 & 66.67 & 70.83 \\
\hline Female (\%) & 31.03 & 33.33 & 29.17 \\
\hline \multicolumn{4}{|l|}{ Age } \\
\hline 25-44 (\%) & 27.59 & 28.57 & 33.34 \\
\hline $45-54(\%)$ & 37.93 & 47.62 & 45.83 \\
\hline 55 and Over $(\%)$ & 34.48 & 23.81 & 20.83 \\
\hline \multicolumn{4}{|l|}{ Residency Status } \\
\hline U.S. Citizen (\%) & 93.10 & 100.00 & 91.67 \\
\hline U.S. Permanent Resident (\%) & 8.90 & 0.00 & 0.00 \\
\hline U.S. Resident Alien (\%) & 0.00 & 0.00 & 8.33 \\
\hline \multicolumn{4}{|l|}{ Highest Level of Education } \\
\hline Master’s Degree (\%) & 13.79 & 9.52 & 45.83 \\
\hline Doctoral Degree (\%) & 72.42 & 85.72 & 45.83 \\
\hline Professional Degree (JD; MD) (\%) & 13.79 & 4.76 & 8.34 \\
\hline \multicolumn{4}{|c|}{ Highest Level of Education's Degree Major } \\
\hline Sport Management-Related (\%) & 27.59 & 47.62 & 29.17 \\
\hline Business-Related (\%) & 34.48 & 23.81 & 33.33 \\
\hline Law-Related (\%) & 10.34 & 4.76 & 8.33 \\
\hline Education-Related (\%) & 17.24 & 9.52 & 20.83 \\
\hline Other Major (\%) & 10.35 & 14.29 & 8.34 \\
\hline \multicolumn{4}{|c|}{ Highest Level of Education's Degree Minor } \\
\hline Sport Management-Related (\%) & 6.90 & 9.52 & 12.50 \\
\hline Business-Related (\%) & 31.03 & 23.81 & 25.00 \\
\hline Other Minor (\%) & 13.79 & 38.10 & 29.17 \\
\hline No Minor (\%) & 48.28 & 28.57 & 33.33 \\
\hline \multicolumn{4}{|c|}{ Highest Level of Education's Degree Graduation } \\
\hline Before $1990(\%)$ & 27.59 & 4.76 & 12.50 \\
\hline Between 1990 and 2000 (\%) & 34.48 & 28.57 & 41.67 \\
\hline After 2000 (\%) & 37.93 & 66.67 & 45.83 \\
\hline \multicolumn{4}{|c|}{ Highest Level of Education's Degree Location } \\
\hline United States (\%) & 96.55 & 100.00 & 100.00 \\
\hline Abroad (\%) & 3.45 & 0.00 & 0.00 \\
\hline \multicolumn{4}{|l|}{ Tenure Status } \\
\hline Tenured Faculty (\%) & 62.07 & 47.62 & 33.33 \\
\hline On a Tenure Track (\%) & 6.90 & 28.57 & 25.00 \\
\hline On a Nontenure Track (\%) & 31.03 & 23.81 & 41.67 \\
\hline \multicolumn{4}{|l|}{ Sport-Related Course Teaching } \\
\hline No $(\%)$ & 13.79 & 33.33 & 12.50 \\
\hline Yes (\%) & 86.21 & 66.67 & 87.50 \\
\hline
\end{tabular}


Table 2 Percentages of Sport Business Programs Variables by Business Accrediting Agencies $\left(N_{\mathrm{AACSB}}=29 ; N_{\mathrm{ACBSP}}=21 ; N_{\mathrm{IACBE}}=24\right)$

\begin{tabular}{|c|c|c|c|c|}
\hline \multirow[b]{2}{*}{ Variable } & \multicolumn{4}{|c|}{ Business Accrediting Agency } \\
\hline & AACSB & ACBSP & IACBE & Tota \\
\hline \multicolumn{5}{|l|}{ Sport Program Department } \\
\hline Stand-Alone Department (\%) & 37.93 & 28.57 & 25.00 & 31.08 \\
\hline Interdisciplinary Department (\%) & 62.07 & 71.43 & 75.00 & 68.92 \\
\hline \multicolumn{5}{|l|}{ Sport Program Status } \\
\hline Fully Integrated Program with the College of Business (COB) (\%) & 93.10 & 95.24 & 100.00 & 95.95 \\
\hline Actively Transitioning to the COB $(\%)$ & 3.45 & 0.00 & 0.00 & 1.35 \\
\hline Housed Outside COB But with Formal Curriculum-Based Ties to COB (\%) & 3.45 & 4.76 & 0.00 & 2.70 \\
\hline \multicolumn{5}{|l|}{ Institution Type } \\
\hline Public (\%) & 55.17 & 14.29 & 4.17 & 27.03 \\
\hline Private $(\%)$ & 44.83 & 85.71 & 95.83 & 72.97 \\
\hline \multicolumn{5}{|l|}{ The Carnegie Classifications } \\
\hline Teaching/Baccalaureate Granting (\%) & 6.89 & 33.34 & 45.83 & 32.43 \\
\hline Comprehensive/Master's Granting (\%) & 27.59 & 57.14 & 41.67 & 40.54 \\
\hline RI/RII/Doctoral Universities (\%) & 65.52 & 9.52 & 12.50 & 27.03 \\
\hline \multicolumn{5}{|l|}{ Sport Program COSMA Interest } \\
\hline Not Interested in COSMA (\%) & 55.17 & 52.38 & 41.67 & 50.00 \\
\hline Not Aware of COSMA (\%) & 34.48 & 19.05 & 20.83 & 25.68 \\
\hline COSMA-Accredited or Pursuing Accreditation (\%) & 10.35 & 28.57 & 37.50 & 24.32 \\
\hline \multicolumn{5}{|l|}{ Teaching Load for a Tenure-Track Faculty } \\
\hline 2-4 Class Sections/Year $(\%)$ & 55.17 & 9.52 & 41.67 & 37.84 \\
\hline 5-6 Class Sections/Year (\%) & 37.93 & 14.29 & 12.50 & 22.97 \\
\hline 7 or More Class Sections/Year (\%) & 6.90 & 76.19 & 45.83 & 39.19 \\
\hline \multicolumn{5}{|l|}{ Sport Program Academic Journals' List } \\
\hline No $(\%)$ & 41.38 & 90.48 & 83.33 & 68.92 \\
\hline Yes $(\%)$ & 58.62 & 9.52 & 16.67 & 31.08 \\
\hline \multicolumn{5}{|l|}{ Required Number of Publications at a Specific Level of Quality } \\
\hline No $(\%)$ & 27.59 & 90.48 & 95.83 & 67.57 \\
\hline Yes $(\%)$ & 72.41 & 9.52 & 4.17 & 32.43 \\
\hline \multicolumn{5}{|l|}{ Minimum Number of Academic Publications Required for Tenure } \\
\hline No Minimum Number (\%) & 13.79 & 66.67 & 79.17 & 50.00 \\
\hline 1-3 Publications $(\%)$ & 37.93 & 14.29 & 4.17 & 20.27 \\
\hline 4-6 Publications (\%) & 27.59 & 19.04 & 16.66 & 21.62 \\
\hline More than 6 Publications (\%) & 20.69 & 0.00 & 0.00 & 8.11 \\
\hline \multicolumn{5}{|l|}{ Sport Program New Faculty Hires (last 5 years) } \\
\hline No Hires $(\%)$ & 34.48 & 42.86 & 29.17 & 35.14 \\
\hline 1 Hire $(\%)$ & 31.03 & 28.57 & 45.83 & 35.14 \\
\hline 2 Hires $(\%)$ & 24.14 & 28.57 & 12.50 & 21.61 \\
\hline 3 or More Hires $(\%)$ & 10.35 & 0.00 & 12.50 & 8.11 \\
\hline \multicolumn{5}{|l|}{ Salary Range Offered to a New Hire (Lecturer/Instructor/Visiting Professor) ${ }^{\mathrm{a}}$} \\
\hline$\$ 0-\$ 50,000(\%)$ & 12.50 & 75.00 & 77.78 & 52.38 \\
\hline$\$ 50,001-\$ 70,000(\%)$ & 75.00 & 25.00 & 22.22 & 42.86 \\
\hline$\$ 70,001-\$ 90,000(\%)$ & 12.50 & 0.00 & 0.00 & 4.76 \\
\hline$\$ 90,001-\$ 110,000(\%)$ & 0.00 & 0.00 & 0.00 & 0.00 \\
\hline More than $\$ 110,000(\%)$ & 0.00 & 0.00 & 0.00 & 0.00 \\
\hline
\end{tabular}




\begin{tabular}{lcccc}
\hline Salary Range Offered to a New Hire (Assistant Professor) $^{\mathrm{a}}$ & & & \\
& & & \\
$\$ 0-\$ 50,000(\%)$ & 0.00 & 11.11 & 54.55 & 21.21 \\
$\$ 50,001-\$ 70,000(\%)$ & 15.38 & 55.56 & 45.45 & 36.37 \\
$\$ 70,001-\$ 90,000(\%)$ & 30.78 & 22.22 & 0.00 & 18.18 \\
$\$ 90,001-\$ 110,000(\%)$ & 38.46 & 11.11 & 0.00 & 18.18 \\
$\quad$ More than $\$ 110,000(\%)$ & 15.38 & 0.00 & 0.00 & 6.06 \\
\hline Salary Range Offered to a New Hire (Associate/Full Professor) ${ }^{\mathrm{a}}$ & & & & \\
$\$ 0-\$ 50,000(\%)$ & 0.00 & 0.00 & 75.00 & 25.00 \\
$\$ 50,001-\$ 70,000(\%)$ & 0.00 & 50.00 & 0.00 & 8.33 \\
$\$ 70,001-\$ 90,000(\%)$ & 33.33 & 50.00 & 25.00 & 33.33 \\
$\$ 90,001-\$ 110,000(\%)$ & 33.33 & 0.00 & 0.00 & 16.67 \\
More than $\$ 110,000(\%)$ & 33.33 & 0.00 & 0.00 & 16.67 \\
\hline
\end{tabular}

${ }^{a}$ AACSB: Salary Range Offered to a New Hire (Lecturer/Instructor/Visiting Professor, $n=8$; Assistant Professor, $n=13$; Associate/Full Professor, $n=6$ ). ACBSP: Salary Range Offered to a New Hire (Lecturer/Instructor/Visiting Professor, $n=4$; Assistant Professor, $n=9$; Associate/Full Professor, $n=2$ ). IACBE: Salary Range Offered to a New Hire (Lecturer/Instructor/Visiting Professor, $n=9$; Assistant Professor, $n=11 ;$ Associate/Full Professor, $n=4)$. 
Table 3 Means and Standard Deviations of Sport Business Programs Variables by Business Accrediting Agencies $\left(N_{\mathrm{AACSB}}=29 ; N_{\mathrm{ACBSP}}=21 ; N_{\mathrm{IACBE}}=24\right)$

\begin{tabular}{|c|c|c|c|c|c|c|c|c|}
\hline \multirow[b]{2}{*}{ Variable } & \multicolumn{2}{|c|}{ AACSB } & \multicolumn{2}{|c|}{ ACBSP } & \multicolumn{2}{|c|}{ IACBE } & \multicolumn{2}{|c|}{ Total } \\
\hline & M & $S D$ & $M$ & $S D$ & $M$ & $S D$ & $M$ & $S D$ \\
\hline \multicolumn{9}{|c|}{ Department's Tenure Allocation (total must sum to 100) } \\
\hline Research Allocation & 34.48 & 13.12 & 19.09 & 11.50 & 16.64 & 14.13 & 24.33 & 15.28 \\
\hline Teaching Allocation & 43.10 & 11.37 & 52.24 & 18.36 & 50.89 & 23.84 & 48.22 & 18.40 \\
\hline Service Allocation & 18.79 & 6.90 & 20.29 & 10.46 & 18.60 & 10.11 & 19.15 & 9.00 \\
\hline Administration Allocation & 3.63 & 9.05 & 8.38 & 14.66 & 13.87 & 22.33 & 8.30 & 16.32 \\
\hline \multicolumn{9}{|l|}{ Student-Faculty Ratio ${ }^{\mathrm{a}}$} \\
\hline Undergraduate & 40.54 & 21.20 & 39.03 & 25.45 & 38.27 & 21.76 & 39.36 & 22.40 \\
\hline Graduate & 13.49 & 18.74 & 18.23 & 19.12 & 11.12 & 14.40 & 14.67 & 17.42 \\
\hline \multicolumn{9}{|c|}{ Sport Program Alumni's Type of Jobs (total must sum to 100) } \\
\hline Sport Business-Related Jobs & 53.51 & 25.46 & 53.95 & 24.15 & 48.29 & 20.83 & 51.94 & 23.49 \\
\hline General Business-Related Jobs & 38.66 & 24.58 & 36.33 & 17.77 & 43.75 & 23.65 & 39.65 & 22.44 \\
\hline Other Type of Jobs & 7.83 & 19.41 & 9.72 & 11.23 & 7.96 & 7.89 & 8.41 & 14.12 \\
\hline \multicolumn{9}{|c|}{ Sport Program Alumni’s Starting Salary/Year $(\$)^{\mathrm{b}}$} \\
\hline Undergraduate & 33714.00 & 7267.34 & 31800.00 & 5157.52 & 29250.00 & 5409.87 & 31788.00 & 6337.99 \\
\hline Graduate & 42111.00 & 10611.84 & 42000.00 & 4472.14 & 58667.00 & 15176.74 & 45000.00 & 11516.29 \\
\hline
\end{tabular}

${ }^{a}$ AACSB: Student-Faculty Ratio (Undergraduate, $n=27$; Graduate, $n=9$ ). ACBSP: Student-Faculty Ratio (Undergraduate, $n=21$; Graduate, $n$

$=8$ ). IACBE: Student-Faculty Ratio (Undergraduate, $n=23$; Graduate, $n=5$ ).

${ }^{\mathrm{b}}$ AACSB: Alumni's Starting Salary/Year (Undergraduate, $n=21$; Graduate, $\left.n=9\right)$. ACBSP: Alumni’s Starting Salary/Year (Undergraduate, $n=$ 15; Graduate, $n=5$ ). IACBE: Alumni's Starting Salary/Year (Undergraduate, $n=16$; Graduate, $n=3$ ). 
Table 4 Multinomial Logit Regression Results of Business Accreditation Agencies Categories: Marginal Effects

\begin{tabular}{lccc}
\hline Variable & Category 1 & Category 2 & Category 3 \\
\hline Sport Program Department (standalone/interdisciplinary) & -.135 & .097 & .038 \\
\hline Department's Research Allocation (\%) & $.027^{* *}$ & -.009 & $-.018^{*}$ \\
\hline Department's Teaching Allocation (\%) & .003 & .000 & -.003 \\
Department's Service Allocation (\%) & -.006 & .006 & -.001 \\
Sport Program COSMA Interest & -.090 & -.043 & $.279^{* *}$ \\
Teaching Load for a Tenure-Track Faculty & $-.273^{*}$ & -.001 & -.007 \\
Undergraduate Student-Faculty Ratio & .003 & .009 & -.001 \\
Graduate Student-Faculty Ratio & .000 & -.063 & -.009 \\
Sport Program New Faculty Hires (last 5 years) & .076 & .001 & -.012 \\
Alumni in Sport Business Jobs (\%) & .005 & -.006 \\
Alumni in General Business Jobs (\%) & .004 & .001 & -.003 \\
\hline Alumni in Other Types of Jobs (\%) & .001 & -.004 \\
\hline
\end{tabular}

Note. Categories: 1 = "The Association to Advance Collegiate Schools of Business (AACSB)," 2 = "Accreditation Council for Business Schools and Programs (ACBSP)," 3 = "The International Assembly for Collegiate Business Education (IACBE)." For the binary coded variable (i.e., sport program department), the result expresses the impact of a discrete change of the variable from 0 to 1 .

${ }^{*} p<.05 ; * * p \leq .001$. 